Bull. Fac .Agric., Cairo Univ., 69: 63- 72( 2018).

\title{
RESPONSE OF MAIZE CROP TO NITROGEN FERTILIZATION LEVELS AND FOLIAR APPLICATION WITH SOME MICRONUTRIENTS
}

\author{
(Received: 10.12.2017)
}

\author{
By \\ E.A . Abo-Marzoka and *M. Kh. Hamadny \\ Crop Physiology Research Department and *Crop intensification Research Department \\ Field Crops Research Institute, Agriculture Research Center, Giza, Egypt
}

\begin{abstract}
Two field experiments were carried out at al-Gemmiza ,Agricultural Research Station, Egypt El- Gharbia Governorate, during the two successive summer seasons of 2016 and 2017 to study the effect of four nitrogen fertilizer applications, i.e. 75, 90, 105 and $120 \mathrm{~kg} \mathrm{~N} / \mathrm{fed}$ and foliar sprays of micronutrient treatments, i.e. Non - fertilized (control), Zn $0.6 \%$, Mn $0.6 \%$, Fe $0.6 \%$ and (Zn $0.2 \%$ $+\mathrm{Mn} 0.2 \%+\mathrm{Fe} 0.2 \%$ ) on the growth, yield and its component and some chemical properties of maize grains of the single cross ( $\mathrm{Sc} 10$ ). The experiments were laid out in a split plot design in a randomized complete block arrangement with four replications. The four nitrogen fertilizer applications, i.e. 75, 90, 105 and $120 \mathrm{~kg} \mathrm{~N} /$ fed were allocated in the main plots and foliar sprays of micronutrient treatments, i.e. Non - fertilized (control), Zn $0.6 \%, \mathrm{Mn} 0.6 \%, \mathrm{Fe} 0.6 \%$ and (Zn $0.2 \%$ $+\mathrm{Mn} 0.2 \%+\mathrm{Fe} 0.2 \%$ ), occupied the sub plots. The results can be summarized as follows : All traits of maize under study (plant height, No. of green leaves /plant and leaf area index at 100 days from planting, ear length, ear weight, weight of kernels/ear, 100-kernel weight, kernels shelling \% , biological yield/fed, grain yield /fed, stover yield /fed, harvest index \%, kernels nitrogen uptake/fed , kernels protein yield /fed, leaf and kernel nitrogen contents, zinc, manganese and iron contents of maize leaves in the two seasons ) showed significant increase by increasing nitrogen fertilizer rate, except, mid tasseling and silking dates, while significantly decreased with increasing nitrogen rates and kernel zinc, manganese and iron contents in both seasons. Application of $120 \mathrm{~kg} \mathrm{~N} / \mathrm{fed}$ significantly gave the maximum values of previous traits. Results revealed that mixed micronutrient foliar spray using ( $\mathrm{Zn} 0.2 \%+\mathrm{Mn} 0.2 \%+\mathrm{Fe} 0.2 \%)$ treatment was the highest treatment for previous growth maize in both seasons. Meanwhile, maize plants which were foliar sprayed singly by $\mathrm{Zn} 0.6$ $\%, \mathrm{Mn} 0.6 \%$ or $\mathrm{Fe} 0.6 \%$ significantly gave the higher values of leaf zinc content, manganese and leaf iron contents, respectively, except leaf and kernel nitrogen contents, in both seasons. The interaction between nitrogen fertilizer of $120 \mathrm{~kg} \mathrm{~N} / \mathrm{fed}$. and foliar spray by the mixture ( $\mathrm{Zn} 0.2 \%+$ Mn $0.2 \%+\mathrm{Fe} 0.2 \%$ ) treatment gave the greatest values of maize traits, i.e. plant height, No. of green leaves/plant and leaf area index at 100 days from planting, No.of kernels/ear, ear weight, weight of kernels/ear, biological yield/fed, grain yield/fed, kernels nitrogen uptake/fed. and kernels protein yield/fed except $50 \%$ tasseling and silking dates , ear length , 100-kernel weight , kernels shelling \% , stover yield/fed., harvest index \%, leaf and kernel nitrogen contents, zinc, manganese and iron contents of maize kernel in both seasons. It could be concluded that fertilization of maize plants by $120 \mathrm{~kg} \mathrm{~N} / \mathrm{fed}$. and foliar spray by ( $\mathrm{Zn} 0.2 \%+\mathrm{Mn} 0.2 \%+\mathrm{Fe} 0.2 \%)$ maximized grain yield / feddan under Gharbia Location .
\end{abstract}

Key words : maize field, fertilizer rate, maximized grain yield.

\section{INTRODUCTION}

Maize (Zea mays L.) ranks third of the most important cereal crops in the world, after wheat and rice. In Egypt, maize is essential for livestock and human consumptions as an available source of carbohydrate, oil, and slightly for protein. The growing area of maize in Egypt during 2013 is about 2,142,857 feddans with a total grain production of $6,500,000$ ton and average grain yield per feddan about 3.033 ton (Egyptian Min. Agric. Statistic Year Book, 2013). The total production supplies $50 \%$ of the required consumption with a gap of $50 \%$ which has to be filled via importation. Increasing maize 
production during the last decade became one of the most important goals of the Egyptian Government to meet human and animal demands. Determination of the required rate of nitrogen fertilization of maize is one of the important practices of great contribution for the highest production of better quality. Nitrogen is a key element for corn productivity as well as in many other field cereal crops. Several investigations reported that increasing nitrogen fertilization rates caused significant increase in growth yield, its components and chemical properties of maize. Shafea and Saffari (2011), Siam et al. (2012), Verma et al. (2012), Raskar et al. (2013) , Manasek et al. (2013) and Azeem et al. (2015) reported that significant increases were observed in plant height, No. of green leaves/plant, leaf area index, ear length, ear weight, weight of kernels/ear, 100-kernel weight, kernels shelling \%, biological yield/fed, grain yield/fed, stover yield/fed, harvest index $\%$, kernels nitrogen uptake/fed, kernels protein yield/fed, leaf and kernel nitrogen contents, zinc, manganese and iron contents of maize leaves with increasing nitrogen fertilization rate. On the other hand, No. of days to $50 \%$ tasseling and silking were significantly decreased

Several investigators reported a positive response of maize plants to micronutrient foliar spaying El-Gizawy (2005), Attia et al. (2011), Shafea and Saffari (2011), Salem and ElGizawy, (2012). Siam et al , (2012) and Raskar et al. (2013) . Micronutrients are required in small amounts and they affect directly or indirectly on photosynthesis and vital processes in plants such as respiration, protein synthesis and reproduction phase (Marschner, 1995). ElAkabawy et al. (2001) stated that the beneficial effects of micronutrients application were recorded by many workers on soils of Egypt.

Zinc plays an important role as a metal component of enzymes (superoxide dismutase, carbonic anhydrase and RNA polymerase) or as a functional, structural, or regulator cofactor of a large number of enzymes. Manganese has an essential role in amino acid synthesis by activating a number of enzymes particularly decarboxylases and dehydrogenases of the tricarboxylic acid cycle. Iron is a constituent of many enzymes involved in the nutritional metabolism, energy transfer, nitrogen reduction and fixation, and lignin formation of plants
(Sadek and Attia (2011), Shafea and Saffari (2011), Siam et al. (2012),Salem and El-Gizawy (2012), Balbaa and Awad (2013) and Raskar et al (2013) reported significant increases in plant height, leaf area index, No. of kernels/ear, kernels weight/ear, weight of 100 - kernel, biological yield, grain yield, stover yield, harvest index, nitrogen uptake/plant, $\mathrm{Zn}, \mathrm{Mn}$ and $\mathrm{Fe}$ contents in leaves as well as $\mathrm{Zn}$ and Fe content in maize kernels by $\mathrm{Zn}$ application. Attia et al. (2011),Sadek and Attia (2011), Siam et al. (2012), Salem and El- Gizawy(2012) and Balbaa and Awad (2013) reported that using Mn significantly increased plant height, No. of green leaves /plant, leaf area index, No. of kernels/ear, kernels weight/ear, weight of 100-kernel, biological yield, grain yield, stover yield, harvest index, Mn uptake, protein content in kernels, nitrogen uptake/plant, $\mathrm{Zn}, \mathrm{Mn}$ and Fe contents in leaves. Al-Kanh and Abdullal (2008),El-Gharieb et al. (2011), Siam et al. (2012), Salem and ElGizawy (2012) and Balbaa and Awad (2013) reported that the application of iron significantly increased plant height, No.of kernels/ear, kernels weight/ear, weight of 100- kernel, grain yield, nitrogen uptake/plant, $\mathrm{Zn}, \mathrm{Mn}$ and $\mathrm{Fe}$ contents in leaves.

The aim of this investigation was to study the effect of nitrogen levels and some micronutrients fertilization on growth,yield, its components and chemical composition of corn grain.

\section{MATERIALS AND METHODS}

Two field experiments were carried out at Al Gemmiza Experiment Agricultural Research Station, El-Gharbia Governorate , Egypt, during the two summers growing seasons 2016 and 2017. The aim of this study was to investigate the effect of nitrogen fertilization rates and some microelements, i.e. zinc, manganese, and iron on growth, yield and its components on a corn variety (single hybrid Sc10) .

Chemical composition of leaves and kernels of maize was carried out. Soil texture of the experimental site was clay and $\mathrm{pH}$ nearly (7.97 and 7.95 in both seasons). The physical and chemical properties of the experimental soil were determined according to the standard procedures described by Black (1965) and represented in Table (1) in each of the two growing seasons. 
Table (1): Soil Physical and chemical properties of the experimental site in the two growing seasons (2016 and 2017).

\begin{tabular}{|c|c|c|}
\hline \multirow{2}{*}{ Properties } & \multicolumn{2}{|c|}{ Seasons } \\
\cline { 2 - 3 } & $\mathbf{2 0 1 6}$ & $\mathbf{2 0 1 7}$ \\
\hline \multicolumn{3}{|c|}{ Mechanical analysis } \\
\hline Course sand \% & 6.26 & 7.59 \\
\hline Find sand \% & 27.91 & 26.64 \\
\hline Silt \% & 14.85 & 14.85 \\
\hline Clay \% & 50.98 & 51.17 \\
\hline Texture grade & clay & clay \\
\hline Chemical analysis & \\
\hline E.C. & 2.33 & 2.19 \\
\hline pH (1 :2.5) & 7.84 & 7.95 \\
\hline $\mathrm{CaCo}_{3} \%$ & 2.86 & 2.70 \\
\hline O.M \% & 2.51 & 2.48 \\
\hline $\mathrm{N} \%($ total) & 0.220 & 0.233 \\
\hline $\mathrm{N}\left(\mathrm{ppm}^{2}\right.$ (available) & 71.31 & 74.15 \\
\hline Soluble cations and anions ( ppm $)$ \\
\hline $\mathrm{Mn}^{++}$ & 8.1 & 8.9 \\
\hline $\mathrm{Fe}^{++}$ & 11.5 & 8.6 \\
\hline $\mathrm{Zn}^{++}$ & 1.9 & 2.2 \\
\hline
\end{tabular}

The experiment included 20 treatments which were the combination of four nitrogen fertilizer treatments and five treatments of microelements.

The four nitrogen fertilization treatments were $75,90,105$ and $120 \mathrm{~kg} \mathrm{~N} / \mathrm{fed}$. Nitrogen fertilizer was applied in form of urea $(46 \% \mathrm{~N})$, and divided into two equal does and applied before the first and second irrigation in each season. Five microelement treatments, i.e. control (without microelements), Zn $0.6 \%$, Mn $0.6 \%, \mathrm{Fe} 0.6 \%$ and $\mathrm{Zn} 0.2 \%+\mathrm{Mn} 0.2 \%$ $+\mathrm{Fe} 0.2 \%$ ). Microelements were applied once as foliar spray after 35 and 45 days from planting in form of Zinc Sulphate $\left(\mathrm{Zn} \mathrm{So}_{4} \cdot 7 \mathrm{H}_{2} \mathrm{O}\right)$, Manganese Sulphate $\left(\mathrm{Mn} \mathrm{So} \mathrm{S}_{4} \mathrm{H}_{2} \mathrm{O}\right)$ and Iron Sulphate $\left(\mathrm{Fe} \mathrm{So}_{4} \cdot \mathrm{7H}_{2} \mathrm{O}\right)$ using Gelatine Powder as a wetting agent to be sure that the solution mostly covered the green parts; the spray solution volume was $600 \mathrm{l} /$ fed. (1.5 and l/plot)

The experimental design was split plot with randomized complete block arrangment with four replications. Nitrogen fertilizer treatments were distributed in the main plots, whereas the microelement treatments were arranged at random in sub plots. The sub plot area was 10.5 $\mathrm{m}^{2}$ and contained five ridges of $3 \mathrm{~m}$ long and 70 $\mathrm{cm}$ apart. The preceding winter crop in the two seasons was Egyptian clover. Experiments were planted on the $15^{\text {th }}$ and the $19^{\text {th }}$ of May in both seasons. The distance between hills was $30 \mathrm{~cm}$ apart. Phosphorous fertilizer was applied in form of Calcium super phosphate $\left(15.5 \% \mathrm{P}_{2} \mathrm{O}_{5}\right)$ at a rate of $100 \mathrm{~kg} / \mathrm{fed}$. during soil preparation in each season. Maize plants were thinned before the first irrigation to one plant/hill. Other recommended cultural practices for growing maize in the region were practiced.

\subsection{Data recorded}

\subsubsection{Growth traits}

Five plants were taken at random from each sub plot to measure the growth traits: plant height $(\mathrm{cm})$ at harvest, No. of green leaves /plant and leaf area at 90 days after planting according to Stickler (1964). Whereas, No. of days to $50 \%$ tasseling and silking were estimated from the whole plants of the plot.

\subsubsection{Yield and its component traits}

Ten ears were taken at random from each sub plot at harvest to record,the yield components: ear length $(\mathrm{cm})$, No. of kernels/ear, ear weight (g), weight of kernels/ear (g) , 100 kernel weight (g) and kernels shelling \% . Meanwhile, biological yield ( $\mathrm{kg} / \mathrm{fed}$ ), grain yield ( $\mathrm{kg} / \mathrm{fed})$, stover yield ( $\mathrm{kg} / \mathrm{fed}$ ) and harvest index $\%$ from the whole yield of plot.

\subsubsection{Chemical analysis}

Maize leaf samples were taken from ear leaf at 100 days from planting and washed with water then dried on an air forced drying oven at $70^{\circ} \mathrm{C}$ for 48 hours . Kernel samples were taken after harvest at random from kernels of ten ears to determine : nitrogen content in the leaves and kernels according to the modified micro Kjeldahl method (A.O.A.C.,1990), nitrogen content of grain and protein yield / fed , as well as Zinc, Manganese and iron (ppm) in the leaves and kernels were determined according to Chapman and Pratt (1961) using atomic absorption spectrophotometer.

\subsection{Statistical analysis}

The analysis of variance was performed according to the procedure described by Gomez and Gomez (1984). Data were statistically analyzed using the MSTAT- C Statistical Software Package (Michigan State University, 1983). Where the F- test showed significant mean squares LS D. test at 0.05 level was used to compare between means.

\section{RESULTS AND DISCUSSION \\ 3.1. Growth traits \\ 3.1.1. Effect of nitrogen fertilization}

Results in Table (2) showed that maize growth characters, plant height, No. of green leaves/plant, leaf area index and No. of ears /fed. were significantly increased by increasing 
Table (2): Effect of nitrogen fertilization rates and foliar spray by some micronutrients and their interaction on growth traits .

\begin{tabular}{|c|c|c|c|c|c|c|c|c|c|c|c|}
\hline \multirow[t]{2}{*}{ Treatment } & \multirow[t]{3}{*}{ 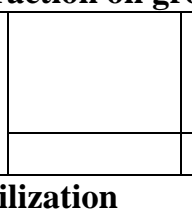 } & \multicolumn{2}{|c|}{\begin{tabular}{|l|} 
No. of days to \\
$50 \%$ tasseling
\end{tabular}} & \multicolumn{2}{|c|}{$\begin{array}{c}\text { No. of days to } \\
50 \% \text { silking }\end{array}$} & \multicolumn{2}{|c|}{$\begin{array}{l}\text { Plant height } \\
\quad(\mathrm{cm})\end{array}$} & \multicolumn{2}{|c|}{$\begin{array}{l}\text { No. of green } \\
\text { leaves/plant }\end{array}$} & \multicolumn{2}{|c|}{$\begin{array}{l}\text { Leaf area } \\
\text { index } \\
\left(\mathrm{cm}^{2}\right)\end{array}$} \\
\hline & & 2016 & 2017 & 2016 & 2017 & 2016 & 2017 & 2016 & 2017 & 2016 & 2017 \\
\hline \multicolumn{11}{|c|}{ Nitrogen fertilization } & \\
\hline \multicolumn{2}{|l|}{$75 \mathrm{~kg} \mathrm{~N} / \mathrm{fed}$} & 60.80 & 64.89 & 64.45 & 65.55 & 285.1 & 287.2 & $\mid 13.63$ & 14.39 & 3.73 & 3.57 \\
\hline \multicolumn{2}{|l|}{$90 \mathrm{~kg} \mathrm{~N} / \mathrm{fed}$} & $\mathbf{5 9 . 9 0}$ & 63.78 & 63.66 & 64.74 & 304.9 & 307.2 & 14.64 & $\mathbf{1 5 . 3 4}$ & 4.34 & 4.12 \\
\hline \multicolumn{2}{|c|}{$105 \mathrm{~kg} \mathrm{~N} / \mathrm{fed}$} & $\mathbf{5 9 . 2 2}$ & 63.05 & 62.97 & 64.08 & 318.1 & 320.9 & 15.42 & $\mathbf{1 6 . 2 1}$ & 4.84 & 4.64 \\
\hline \multicolumn{2}{|c|}{$120 \mathrm{~kg} \mathrm{~N} / \mathrm{fed}$} & $\mathbf{5 8 . 3 2}$ & 62.13 & 61.46 & 62.51 & 328.8 & 330.7 & 15.99 & 16.80 & 5.23 & 4.98 \\
\hline L.S.D at $5 \%$ & & 0.85 & 0.98 & 1.02 & 1.23 & 8.26 & 10.15 & 0.64 & 072 & 0.22 & 0.29 \\
\hline \multicolumn{12}{|c|}{ Microelements fertilization } \\
\hline \multicolumn{2}{|l|}{ Zero } & 60.47 & 64.39 & \begin{tabular}{|l|}
64.40 \\
\end{tabular} & 65.44 & 303.9 & 305.3 & 14.12 & 14.89 & 4.18 & 4.00 \\
\hline \multicolumn{2}{|l|}{$\mathbf{Z n}$} & $\mathbf{5 9 . 4 5}$ & 63.42 & 63.02 & 64.13 & 311.1 & 314.0 & 15.05 & $\mathbf{1 5 . 8 3}$ & 4.58 & 4.37 \\
\hline \multicolumn{2}{|l|}{ Mn } & $\mathbf{5 9 . 8 5}$ & 63.78 & 63.42 & 64.42 & 307.6 & 309.2 & 14.91 & 15.67 & 4.51 & 4.29 \\
\hline \multicolumn{2}{|l|}{$\mathbf{F e}$} & 59.35 & 63.18 & 62.79 & 63.89 & 308.7 & 311.3 & 15.17 & 15.93 & 4.65 & 4.44 \\
\hline \multirow{2}{*}{\multicolumn{2}{|c|}{$\begin{array}{l}\text { Zn+Mn+Fe } \\
\text { L.S.D at 5\% }\end{array}$}} & 58.67 & 62.57 & 62.04 & 63.23 & 314.9 & 317.8 & 15.33 & 16.12 & 4.75 & 4.54 \\
\hline & & 0.58 & 0.73 & 0.88 & 0.72 & 2.74 & 3.55 & \begin{tabular}{|l|}
0.19 \\
\end{tabular} & 0.23 & $\mathbf{0 . 0 7}$ & 0.09 \\
\hline \multicolumn{12}{|l|}{ Nitrogen $x$} \\
\hline \multirow{5}{*}{$75 \mathrm{~kg} \mathrm{~N} / \mathrm{fed}$} & Zero & 61.88 & 66.20 & 66.01 & 67.21 & 276.7 & 277.1 & 12.82 & 13.78 & 3.32 & 3.23 \\
\hline & $\mathbf{Z n}$ & 60.75 & 64.99 & 64.40 & 65.55 & 288.0 & 293.0 & 13.75 & 14.50 & 3.79 & 3.63 \\
\hline & Mn & 61.20 & 65.48 & \begin{tabular}{|l|}
64.63 \\
\end{tabular} & 65.79 & 283.2 & 282.5 & 13.63 & $\mathbf{1 4 . 3 1}$ & 3.71 & 3.54 \\
\hline & $\mathrm{Fe}$ & 67.25 & 64.26 & \begin{tabular}{|l|}
64.17 \\
\end{tabular} & 65.08 & \begin{tabular}{|l|l|}
283.8 \\
\end{tabular} & 286.9 & 13.88 & 14.61 & 3.85 & 3.68 \\
\hline & $\mathrm{Zn}+\mathrm{Mn}+\mathrm{Fe}$ & 60.53 & 63.54 & 63.02 & 64.13 & 294.0 & 296.4 & 14.06 & 14.79 & 3.95 & 3.78 \\
\hline \multirow{5}{*}{$90 \mathrm{~kg} \mathrm{~N} / \mathrm{fed}$} & Zero & 59.63 & 64.75 & \begin{tabular}{|l|}
65.09 \\
\end{tabular} & 66.03 & 299.3 & 299.2 & 13.68 & $\mathbf{1 4 . 4 5}$ & 3.93 & 3.75 \\
\hline & Zn & 60.98 & 63.78 & \begin{tabular}{|l|}
63.48 \\
\end{tabular} & 64.60 & 307.1 & 309.3 & 14.81 & 15.51 & 4.40 & 4.18 \\
\hline & Mn & $\mathbf{5 9 . 8 5}$ & 64.02 & \begin{tabular}{|l|l|}
63.94 \\
\end{tabular} & 65.08 & \begin{tabular}{|l|}
302.7 \\
\end{tabular} & 305.1 & 14.61 & 15.26 & 4.31 & 4.07 \\
\hline & $\mathbf{F e}$ & 60.08 & 63.54 & 63.25 & 64.36 & 303.5 & 307.5 & $\mid 14.97$ & 15.64 & 4.48 & 4.25 \\
\hline & $\mathrm{Zn}+\mathrm{Mn}+\mathrm{Fe}$ & 59.63 & 62.81 & 62.56 & 63.65 & 312.1 & 314.9 & 15.14 & 15.85 & 4.59 & 4.37 \\
\hline \multirow{5}{*}{$105 \mathrm{kgN} / \mathrm{fed}$} & Zero & $\mathbf{5 8 . 9 5}$ & 63.78 & \begin{tabular}{|l|}
63.94 \\
\end{tabular} & 65.08 & 314.2 & 317.0 & 14.63 & 15.32 & 4.52 & 4.32 \\
\hline & $\mathbf{Z n}$ & 60.08 & 63.05 & 63.02 & 64.13 & 319.5 & 321.9 & 15.53 & 16.38 & 4.88 & 4.67 \\
\hline & Mn & 59.18 & 63.29 & 63.25 & 64.13 & 316.3 & 319.3 & 15.48 & 16.25 & 4.63 & 4.60 \\
\hline & $\mathbf{F e}$ & 59.63 & 62.81 & 62.56 & 63.65 & 318.2 & 320.1 & 15.66 & 16.48 & 4.95 & 4.74 \\
\hline & $\mathrm{Zn}+\mathrm{Mn}+\mathrm{Fe}$ & $\mathbf{5 8 . 9 5}$ & 62.32 & 62.10 & 63.41 & 322.4 & 326.3 & $\mid 15.81$ & 16.64 & 5.05 & 4.85 \\
\hline \multirow{5}{*}{$120 \mathrm{kgN} / \mathrm{fed}$} & Zero & 58.28 & 62.81 & 62.56 & 63.41 & 325.2 & 328.1 & 15.38 & 16.04 & 4.96 & $\mathbf{7 . 7 0}$ \\
\hline & Zn & $\mathbf{5 8 . 9 5}$ & 61.84 & 61.18 & 62.23 & 330.0 & 331.7 & 16.10 & 16.91 & 5.26 & 5.01 \\
\hline & Mn & $\mathbf{5 8 . 0 5}$ & 62.32 & 61.87 & 62.70 & 328.1 & 329.9 & 15.97 & 16.83 & 5.20 & 4.96 \\
\hline & $\mathrm{Fe}$ & 58.28 & 62.08 & 61.18 & 62.46 & 329.4 & 330.6 & 16.20 & 17.01 & 5.32 & 5.08 \\
\hline & $\mathbf{Z n}+\mathrm{Mn}+\mathrm{Fe}$ & 57.83 & 61.60 & \begin{tabular}{|l|}
60.49 \\
\end{tabular} & 61.75 & 331.01 & 333.5 & \begin{tabular}{|l|l|}
16.30 \\
\end{tabular} & 17.20 & 5.39 & 5.16 \\
\hline \multicolumn{2}{|c|}{ L.S.D at 5\% } & N.S & N.S & N.S & N.S & 5.79 & 7.12 & \begin{tabular}{|l|}
0.34 \\
\end{tabular} & $\mathbf{0 . 4 3}$ & 0.14 & 0.15 \\
\hline
\end{tabular}

nitrogen fertilizer rate up to $120 \mathrm{~kg} \mathrm{~N} / \mathrm{fed}$. in 2016 and 2017 seasons. On the other hand, increasing nitrogen fertilizer rate induced earlier tasseling and silking in the two seasons. Increases in maize growth traits with increasing nitrogen fertilizer may be attributed to the role of nitrogen in promoting the cell division, vegetative growth and encouraging the juvenility and active persistence of meristimatic tissues during maize growth. Many investigators reported similar results as El - Gedwy (2007), Attia et al. (2011), Siam et al. (2012), Verma et al. (2012) and Azeem et al. (2015).

\subsubsection{Effect of foliar spray by microelements}

Data presented in Table (2) showed that micronutrents foliar spray using $\mathrm{Zn} 0.2 \%+\mathrm{Mn}$
$0.2 \%+\mathrm{Fe} 0.2 \%$ mixture was the most effective treatment for plant height, No. of green leaves/plant and leaf area index in the both seasons . Also, adding of $\mathrm{Zn} 0.2 \%+\mathrm{Mn} 0.2 \%$ $+\mathrm{Fe} 0.2 \%$ mixture induced earlier tasseling and silking \% of in 2016 and 2017 seasons.

Treatments involving the application of single microelement showed a slight and significant superiority over the control without microelements application. The increase in maize growth traits with the application of microelements especially ( Zn $0.2 \%+\mathrm{Mn} 0.2 \%$ $+\mathrm{Fe} 0.2 \%$ ) mixture may be due to the synergetic role of microelements in directly or indirectly improving photosynthesis and vital processes in plant such as respiration, protein 
synthesis, reproduction phase, biochemical and physiological activities. Many investigators reported similar results as Rego et al. (2007), Kanwal et al. (2010), Attia et al. (2011), Salem and El - Gizawy (2012), Siam et al. (2012) and Balbaa and Awad (2013).

\subsubsection{Interaction effect}

Table (2) showed that the interaction had significant effect on plant height, No. of green leaves/plant and leaf area index in both of 2016 and 2017 seasons. The highest values of plant height, No. of green leaves/plant and leaf area index were recorded from maize plants were fertilized by $120 \mathrm{~kg} \mathrm{~N} /$ fed. with foliar spray by $\mathrm{Zn} 0.2 \%+\mathrm{Mn} 0.2 \%+\mathrm{Fe} 0.2 \%$ treatment. Such results are in accordance with those obtained by Attia et al. (2011), Mehasen and Saeed (2006) and Siam et al. (2012) .

\subsection{Yield and its component \\ 3.2.1.Effect of nitrogen fertilization}

Data present in Tables (3 and 4) indicated that increasing nitrogen fertilization rate from 75 to 90,105 and $120 \mathrm{~kg} \mathrm{~N} / \mathrm{fed}$ caused significant increases in yield and its components of maize in both seasons .

The highest nitrogen rate $(120 \mathrm{~kg} \mathrm{~N} / \mathrm{fed})$ was more effective in increasing values of all studied traits, also, produced the maximum grain yield/fed and proved significant superiority to other nitrogen rates. The treatments of 70, 95 , 105 and $120 \mathrm{~kg} \mathrm{~N} / \mathrm{fed}$ significantly increased grain yield / fed of maize by $26.48,56.16$ and $74.37 \%$ in the first season, and by $29.64,53.35$ and $71.89 \%$ in the second season, respectively, when compared with applying $75 \mathrm{~kg} \mathrm{~N} / \mathrm{fed}$. The present results clearly indicate that nitrogen application induced increases in yield and yield components of maize showing the major role of this vital nutritive element. The increase in nitrogen application encourages photosynthesis activities and the metabolic efficiency which contributes to enhancing the accumulation of the produced metabolites of maize. Many investigators reported similar results Attia et al. (2011), El -Gharieb et al (2011), Siam et al.(2012), Verma et al. (2012), Raskar et al., (2013) and Azeem et al. (2015).

\subsubsection{Effect of foliar spray by microelements}

Data recorded in Tables ( 3 and 4 ) indicated that the yield and its component traits studied of maize, i.e. ear length, No. of kernels /ear, ear weight, weight of kernels/ear, 100 - kernel weight, kernels shelling \%,biological yield, grain yield, stover yield, harvest index \%, kernels nitrogen uptake and kernels protein yield significantly increased by the application of $\mathrm{Zn}$ $0.6 \%, \mathrm{Mn} 0.6$ and $\mathrm{Fe} 0.6$,individually or in a mixture in the second seasons. Such increases were particularly significant by the mixture ( $\mathrm{Zn}$ $0.2+\mathrm{Mn} 0.2+\mathrm{Fe} 0.2$ ) with regard to ear and yield traits of maize under study. In 2016 season, the grain yield / fed increased by $20.99,15.76$, 19.92 and $30.15 \%$ whith microelements application of $\mathrm{Zn} 0.6$, Mn $0.6, \mathrm{Fe} 0.6$ and ( Zn $0.2+\mathrm{Mn} 0.2+\mathrm{Fe} 0.2$ ) respectively over the control treatment ( no microelements applied) . Similar results were noticed in 2017 season, where the grain yield / fed increased by about $18.28,13.96,18.10$ and $28.17 \%$, respectively. Increases in maize yield and its components with the application of microelements as foliar spray, especially ( $\mathrm{Zn}$ $0.2 \%+\mathrm{Mn} 0.2 \%+\mathrm{Fe} 0.2 \%$ ) treatment may be due to the synergetic role of microelements in improving directly or indirectly photosynthesis, vital processes in plant such as respiration., protein synthesis, reproduction phase, biochemical and physiological activities . Many investigators reported similar results Attia et al. (2011) , El - Gharieb et al.,(2011), Sadek and Attia (2011), Salem and El-Gizawy (2012), Balbaa and Awad (2013) and Raskar et al. (2013) .

\subsubsection{Interaction effect}

Significant effects of the interactions between nitrogen fertilization and foliar spray of microelements were obtained for some yield and its components of maize namely No. of kernels / ear, ear weight , weight of kernels/ear, biological yield /fed , grain yield/fed., kernels nitrogen uptake / fed and kernels protein yield / fed. in the both seasons (Tables 3 and 4). The greatest values of previous traits were recorded on maize plants when fertilized by $120 \mathrm{~kg} \mathrm{~N} /$ fed along with foliar spray of ( $\mathrm{Zn} 0.2 \%+\mathrm{Mn} 0.2 \%+\mathrm{Fe}$ $0.2 \%$ ) mixture. Such results are in accordance with those reported by El-Gharieb et al. (2011), Mehasen and Saeed (2006), Attia et al. (2011) and Raskar et al. (2013) .

\subsection{Chemical properties}

\subsubsection{Effect of nitrogen fertilization}

Results presented in Table (5) clearly show that the increase in nitrogen rate from 75 to 90 , 105 and $120 \mathrm{~kg} \mathrm{~N} / \mathrm{fed}$. caused significantly increases in kernel nitrogen content as well as nitrogen, Zinc, manganese and iron contents of maize leaves during 2016 and 2017 seasons. The highest nitrogen rate $(120 \mathrm{~kg} \mathrm{~N} / \mathrm{fed}$.) was more effective in increasing values of the above 
Table (3): Effect of nitrogen fertilization rates and foliar spray by microenutrients and their interactions on ear length (cm), number of kernels/ear, ear weight (g), weight of kernels / ear (g), 100-kernel weight (g) and shelling \% of maize in 2016 and 2017 seasons.

\begin{tabular}{|c|c|c|c|c|c|c|c|c|c|c|c|c|c|}
\hline \multirow[t]{2}{*}{ Treatment } & \multirow[t]{2}{*}{. } & \multicolumn{2}{|c|}{$\begin{array}{l}\text { Ear length } \\
\quad(\mathrm{cm})\end{array}$} & \multicolumn{2}{|c|}{$\begin{array}{c}\text { No. of } \\
\text { kernels/ear }\end{array}$} & \multicolumn{2}{|c|}{$\begin{array}{c}\text { Ear weight } \\
(\mathrm{g})\end{array}$} & \multicolumn{2}{|c|}{$\begin{array}{c}\text { Weight of } \\
\text { kernels/ear } \\
(\mathrm{g})\end{array}$} & \multicolumn{2}{|c|}{$\begin{array}{c}\text { 100-kernel } \\
\text { weight } \\
(\mathrm{g}) \\
\end{array}$} & \multicolumn{2}{|c|}{$\begin{array}{c}\text { shelling } \\
\%\end{array}$} \\
\hline & & 2016 & 2017 & 2016 & 2017 & 2016 & 2017 & 2016 & 2017 & 2016 & 2017 & 2016 & 2017 \\
\hline \multicolumn{14}{|c|}{ Nitrogen fertilization } \\
\hline \multicolumn{2}{|c|}{$75 \mathrm{~kg} \mathrm{~N} / \mathrm{fed}$} & 17.7 & 18.7 & 370.2 & 388.8 & 134.2 & 144.9 & $\mathbf{1 0 4 . 5}$ & 115.8 & 33.1 & 34.4 & 79.4 & 81.4 \\
\hline \multicolumn{2}{|c|}{$90 \mathrm{~kg} \mathrm{~N} /$ fed } & 19.8 & 21.0 & 434.1 & 458.1 & 160.0 & 175.3 & 129.4 & 146.0 & 35.1 & 36.8 & 82.5 & 84.9 \\
\hline \multicolumn{2}{|c|}{$105 \mathrm{~kg} \mathrm{~N} / \mathrm{fed}$} & 21.6 & 22.9 & 508.5 & 520.9 & 193.0 & 204.7 & 159.3 & 173.7 & 36.9 & 38.5 & 84.2 & 86.6 \\
\hline \multicolumn{2}{|c|}{$120 \mathrm{~kg} \mathrm{~N} / \mathrm{fed}$} & 22.8 & 24.3 & 553.7 & 565.8 & 213.9 & 226.0 & 179.0 & 194.5 & 38.1 & 39.8 & 85.3 & 87.8 \\
\hline \multirow{2}{*}{\multicolumn{3}{|c|}{\begin{tabular}{|c|r} 
L.S.D at 5\% & 1.3 \\
Microelements fertilization
\end{tabular}}} & 1.2 & 32.2 & 29.3 & 11.2 & 14.3 & 6.9 & 6.8 & 1.4 & 1.1 & 1.8 & 1.9 \\
\hline & & & & & & & & & & & & & \\
\hline \multicolumn{2}{|l|}{ Zero } & 19.0 & 20.2 & 428.5 & 449.1 & 158.9 & 171.3 & 127.1 & 141.2 & 34.5 & 35.9 & 81.1 & 83.6 \\
\hline \multicolumn{2}{|l|}{ Zn } & 20.7 & 21.9 & 480.0 & 494.1 & 178.3 & 190.0 & 146.7 & 160.7 & 35.7 & 37.3 & 83.6 & 86.0 \\
\hline \multicolumn{2}{|l|}{ Mn } & 20.5 & 21.5 & 457.9 & 473.3 & 175.5 & 187.4 & 142.2 & 156.1 & 36.3 & 37.8 & 82.3 & 84.6 \\
\hline \multicolumn{2}{|l|}{$\mathbf{F e}$} & 21.0 & 22.3 & 469.9 & 485.5 & 177.0 & 190.0 & 144.5 & 159.2 & 36.0 & 37.6 & 82.9 & 85.1 \\
\hline \multicolumn{2}{|c|}{$\mathrm{Zn}+\mathrm{Mn}+\mathrm{Fe}$} & 21.3 & 22.7 & 495.6 & 515.0 & 186.6 & 200.0 & 154.7 & 170.3 & 36.6 & 38.0 & 84.3 & 86.7 \\
\hline \multicolumn{2}{|c|}{ L.S.D at $5 \%$} & 0.8 & 0.6 & 9.2 & 10.5 & 4.6 & 5.2 & 2.3 & 2.4 & 0.4 & 0.3 & 0.7 & 0.8 \\
\hline \multicolumn{14}{|c|}{ Nitrogen X Microelements fertilization interaction } \\
\hline \multirow{5}{*}{$75 \mathrm{~kg} \mathrm{~N} / \mathrm{fed}$} & Zero & 15.1 & $\mathbf{1 6 . 0}$ & 330.8 & 354.3 & 115.7 & 128.1 & 86.9 & 99.0 & 30.9 & 32.3 & 76.6 & 78.9 \\
\hline & $\mathbf{Z n}$ & 18.2 & 19.2 & 388.1 & 401.8 & 138.6 & 148.4 & 109.4 & 119.7 & 33.2 & 34.4 & 80.5 & 82.4 \\
\hline & Mn & 18.0 & 19.0 & 360.6 & 373.4 & 135.8 & 143.2 & 104.2 & 113.2 & 34.0 & 35.0 & 78.3 & 80.7 \\
\hline & $\mathbf{F e}$ & 18.5 & 19.5 & 372.8 & 389.6 & 135.9 & 146.8 & 106.2 & 117.3 & 33.5 & 34.8 & 79.7 & 81.5 \\
\hline & $\mathrm{Zn}+\mathrm{Mn}+\mathrm{Fe}$ & 18.9 & 19.8 & 399.0 & 424.7 & 144.9 & 157.9 & 115.9 & 129.7 & 34.2 & 35.3 & 81.6 & 83.8 \\
\hline \multirow{5}{*}{$90 \mathrm{~kg} \mathrm{~N} / \mathrm{fed}$} & Zero & 18.2 & 19.5 & 392.3 & 418.7 & 142.8 & 154.9 & 112.9 & 126.5 & 33.9 & 34.9 & 80.6 & 83.3 \\
\hline & $\mathbf{Z n}$ & 20.0 & 21.0 & 449.3 & 471.9 & 162.5 & 179.2 & 132.6 & 150.5 & 34.8 & 36.9 & 83.3 & 85.7 \\
\hline & Mn & 19.8 & 20.8 & 418.6 & 447.4 & 157.2 & 175.0 & 126.5 & 144.8 & 35.6 & 37.4 & 82.1 & 84.4 \\
\hline & $\mathbf{F e}$ & 20.3 & 21.5 & 435.1 & 460.2 & 161.2 & 178.5 & 130.3 & 148.3 & 35.3 & 37.2 & 82.5 & 84.8 \\
\hline & $\mathrm{Zn}+\mathrm{Mn}+\mathrm{Fe}$ & 20.7 & 22.0 & 474.9 & 492.4 & 176.1 & 188.8 & 144.8 & 160.0 & 35.9 & 37.5 & 83.9 & 86.5 \\
\hline \multirow{5}{*}{$105 \mathrm{~kg} \mathrm{~N} / \mathrm{fed}$} & Zero & 20.3 & 21.8 & 463.1 & 480.1 & 173.7 & 186.3 & 140.7 & 155.7 & 35.8 & 37.5 & 82.6 & 85.3 \\
\hline & Zn & 21.8 & 23.0 & 521.0 & 532.8 & 195.9 & 207.5 & 162.9 & 177.4 & 36.8 & 38.5 & 84.8 & 87.3 \\
\hline & Mn & 21.5 & 22.5 & 504.8 & 514.4 & 194.5 & 205.1 & 159.8 & 173.0 & 37.3 & 38.9 & 83.8 & 86.1 \\
\hline & $\mathbf{F e}$ & 22.1 & 23.3 & 519.4 & 525.3 & 197.9 & 207.5 & 163.4 & 175.8 & 37.1 & 38.7 & 84.2 & 86.5 \\
\hline & $\mathrm{Zn}+\mathrm{Mn}+\mathrm{Fe}$ & 22.5 & 23.7 & 534.1 & 552.1 & 203.0 & 217.2 & 169.9 & 186.3 & 37.5 & 39.0 & 85.4 & 87.6 \\
\hline & Zero & 22.3 & 23.4 & 527.9 & 543.1 & 203.2 & 215.7 & 168.1 & 183.8 & 37.5 & 39.1 & 84.4 & 87.0 \\
\hline & $\mathbf{Z n}$ & 22.8 & 24.3 & 561.6 & 569.9 & 216.2 & 225.0 & 182.0 & 195.1 & 38.2 & 39.6 & 84.9 & 88.5 \\
\hline $120 \mathrm{~kg} \mathrm{~N} / f e d$ & Mn & 22.6 & 24.0 & 547.5 & 558.1 & 214.5 & 226.3 & 178.3 & 193.3 & 38.4 & 40.0 & 84.8 & 87.2 \\
\hline & $\mathbf{F e}$ & 23.0 & 24.6 & 552.3 & 567.1 & 212.9 & 227.1 & 178.0 & 195.3 & 38.0 & 39.8 & 85.3 & 87.7 \\
\hline & $\mathrm{Zn}+\mathrm{Mn}+\mathrm{Fe}$ & 23.3 & 25.3 & 574.2 & 590.7 & 222.5 & 235.6 & 188.3 & 204.9 & 38.6 & 40.3 & 86.3 & 88.7 \\
\hline L.S.D & at $5 \%$ & N.S & N.S & 18.4 & 18.9 & 8.2 & 11.5 & 5.6 & 4.5 & N.S & N.S & N.S & N.S \\
\hline
\end{tabular}

traits, but, there was no significant difference between applications $105 \mathrm{~kg} \mathrm{~N} / \mathrm{fed}$. and $120 \mathrm{~kg}$ $\mathrm{N} /$ fed. in chemical properties under study. It could be concluded that the increase in $\mathrm{N}$ supply improved the leaves and kernels quality. These results are in agreement with those obtained by El-Gizawy (2000) ,El - Gedwy (2007), Alizadeh (2010), El - Gharieb et al. (2011), Shafea and Saffari (2011), Siam et al. (2012) and Manasek et al. (2013) .

3.3.2. Effect of foliar spray by microelements treatments

Results presented in Table (5) revealed that the differences between the studied five microelements , i.e. no-microelements , Zn 0.6 $\%, \mathrm{Mn} 0.6 \%$, Fe $0.6 \%$ and ( $\mathrm{Zn} 0.2 \%+\mathrm{Mn}$ $0.2 \%+\mathrm{Fe} 0.2 \%$ ) treatments on the chemical properties of leaves and kernels of maize in 2016 and 2017 seasons were significant,except nitrogen content in the leaves and kernels of maize which were not significant .These results revealed that application of mixture of ( $\mathrm{Zn} 0.2$ $\%+\mathrm{Mn} 0.2 \%+\mathrm{Fe} 0.2 \%$ ) gave the significantly greatest values of zinc, manganese and iron contents of maize kernels in both seasons. Meanwhile, maize plants treated with foliar 
Table (4): Effect of nitrogen fertilization rates and foliar spray by some microenutrients and interactions on biological yield (kg/fed), grain yield (kg/fed), stover yield (kg/fed.), harvest index (\%), kernels nitrogen uptake (kg / fed) and kernels protein yield (kg/fed) of maize in 2016 and 2017 seasons.

\begin{tabular}{|c|c|c|c|c|c|c|c|c|c|c|c|c|c|}
\hline \multirow[t]{2}{*}{ Treatment } & & \multicolumn{2}{|c|}{$\begin{array}{c}\text { biological } \\
\text { yield } \\
\text { (t/fed) }\end{array}$} & \multicolumn{2}{|c|}{$\begin{array}{c}\text { Grain yield } \\
\quad(t / \text { fed })\end{array}$} & \multicolumn{2}{|c|}{$\begin{array}{c}\text { Stover yield } \\
\quad(t / \text { fed })\end{array}$} & \multicolumn{2}{|c|}{$\begin{array}{c}\text { Harvest } \\
\text { index }(\%)\end{array}$} & \multicolumn{2}{|c|}{$\begin{array}{c}\text { Kernels } \\
\text { nitrogen } \\
\text { uptake } \\
\text { (kg/fed) }\end{array}$} & \multicolumn{2}{|c|}{$\begin{array}{c}\text { Kernels } \\
\text { protein yield } \\
(\mathrm{kg} / \mathrm{fed})\end{array}$} \\
\hline & & 2016 & 17 & 016 & 017 & 2016 & 017 & 2016 & 2017 & 2016 & 2017 & 6 & $\mathbf{1 7}$ \\
\hline \multicolumn{14}{|c|}{ Nitrogen fertilization } \\
\hline \multicolumn{2}{|c|}{$75 \mathrm{~kg} \mathrm{~N} / \mathrm{fed}$} & 5.806 & 180 & 2.094 & 2.316 & .712 & 3.864 & 36.07 & 7.48 & 19.49 & 19.21 & 80 & 120.08 \\
\hline \multicolumn{2}{|c|}{$90 \mathrm{~kg} \mathrm{~N} /$ fed } & 7.058 & 565 & 2.648 & 3.003 & .410 & 4.562 & 37.52 & 9.70 & 26.81 & 26.95 & & \\
\hline \multicolumn{2}{|c|}{$105 \mathrm{~kg}$ N/fed } & 8.210 & 666 & 3.270 & 3.552 & 4.940 & 5.114 & 39.83 & 40.99 & 35.16 & 33.74 & .73 & .88 \\
\hline \multicolumn{2}{|c|}{$120 \mathrm{~kg} \mathrm{~N} / \mathrm{fed}$} & 8.913 & 362 & 3.652 & 3.981 & 5.261 & 5.381 & 41.97 & 42.52 & 40.67 & 39.27 & & .46 \\
\hline L.S.D at 5 & & 3.98 & .26 & 2.10 & 2.32 & 134 & 1.54 & 1.28 & & 4.86 & 5.26 & & .61 \\
\hline \multicolumn{14}{|c|}{ Microelements fertilization } \\
\hline \multicolumn{2}{|l|}{ Zero } & 6.830 & 259 & 2.486 & 2.777 & .344 & 4.482 & 6.40 & 3.26 & 4.93 & 24.73 & 80 & .58 \\
\hline \multicolumn{2}{|l|}{ Zn } & 7.685 & 115 & 3.006 & 3.285 & .679 & 4.830 & 39.12 & 48 & 1.92 & 30.82 & & 63 \\
\hline \multicolumn{2}{|l|}{ Mn } & 7.391 & 44 & 2.876 & 3.165 & .515 & 4.679 & 38.91 & 40 & 29.93 & 29.17 & & 31 \\
\hline \multicolumn{2}{|l|}{$\mathbf{F e}$} & 7.567 & 18 & 2.980 & 3.280 & .587 & 4.738 & 39.38 & 40.91 & 31.36 & 30.53 & & \\
\hline \multicolumn{2}{|c|}{$\mathrm{Zn+Mn+Fe}$} & 8.012 & & & 3.560 & & & 40.36 & & 4.52 & 33.72 & 73 & \\
\hline L.S.D at 5 & & 1.20 & 1.35 & 7.08 & .69 & 8 & 8 & 0.71 & & 1.51 & 1.76 & & \\
\hline \multicolumn{14}{|l|}{ Nitrogen $X$} \\
\hline \multirow{5}{*}{$75 \mathrm{~kg} \mathrm{~N} / \mathrm{fed}$} & & 5.16 & 21 & 1.642 & 1.872 & 3.518 & 49 & 31.82 & 3.91 & 3.93 & 14.16 & 07 & 53 \\
\hline & & & & & & & & 36.95 & & & & & \\
\hline & & 5.708 & 042 & 2.059 & 36 & 3.649 & 06 & 36.07 & 01 & 9.09 & 18.55 & & .96 \\
\hline & & 5.866 & & 2.165 & & & & 36.91 & 22 & 0.39 & 20 & & \\
\hline & $n+M$ & 6.301 & 738 & 2.390 & 2.669 & 3.911 & 4.069 & 37.93 & 39.61 & 22.94 & 22.82 & .39 & .62 \\
\hline \multirow{5}{*}{$90 \mathrm{~kg} \mathrm{~N} /$ fed } & & 6.203 & 626 & 2.213 & 2.505 & 3.990 & 4.121 & 35.68 & 37.81 & 21.09 & 21.19 & 84 & .45 \\
\hline & & 7.296 & 7.824 & 2.728 & 3.099 & 4.568 & 4.725 & 37.39 & 39.61 & 28.08 & 28.23 & .51 & 6.46 \\
\hline & $n$ & 6.886 & 464 & 2.555 & 2.949 & 4.331 & 4.515 & 37.10 & 39.51 & 25.73 & 26.39 & .82 & 1.89 \\
\hline & & 7.164 & 7.686 & 2.701 & 3.092 & 4.463 & 4.594 & 37.70 & 40.23 & 27.52 & 27.98 & & 1.87 \\
\hline & $\overline{Z n+1}$ & 7.746 & 226 & 3.047 & 3.370 & 4.699 & 4.856 & 39.34 & 40.97 & 31.64 & 30.96 & .74 & 3.51 \\
\hline \multirow{5}{*}{$105 \mathrm{~kg} \mathrm{~N} / \mathrm{fed}$} & & 7.508 & 001 & 2.757 & 3.066 & 4.751 & 4.935 & 36.72 & 38.32 & 28.52 & 28.14 & 178.28 & 5.88 \\
\hline & & 8.402 & $\mathbf{8 . 8 3 7}$ & 3.362 & 3.639 & 5.040 & 5.198 & 40.01 & 41.18 & 36.64 & 34.92 & 228.97 & 218.28 \\
\hline & & 8.127 & 8.568 & 3.271 & 3.528 & 4.856 & 5.040 & 40.25 & 41.18 & 34.86 & 33.18 & 217.88 & 7.37 \\
\hline & 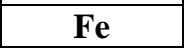 & 8.327 & 8.753 & 3.392 & 3.634 & 4.935 & 5.119 & 40.73 & 41.52 & 36.69 & 34.64 & 229.31 & 216.50 \\
\hline & $\mathbf{Z n + M n}$ & 8.688 & 9.169 & 3.569 & 3.893 & 5.119 & 5.276 & 41.08 & 42.46 & 39.07 & 37.82 & 244.19 & 6.37 \\
\hline \multirow{5}{*}{$120 \mathrm{~kg} \mathrm{~N} / \mathrm{fed}$} & Zero & 8.446 & 8.889 & 3.327 & 3.665 & 5.119 & 5.224 & 39.39 & 41.23 & 36.16 & 35.43 & 226.00 & 21.46 \\
\hline & $\mathbf{Z n}$ & 9.049 & 9.444 & 3.720 & 3.984 & 5.329 & 5.460 & 41.11 & 42.19 & 41.89 & 39.65 & 261.81 & 247.84 \\
\hline & Mn & 8.845 & 9.301 & 3.621 & 3.946 & 5.224 & 5.355 & 40.94 & 42.43 & 40.02 & 38.57 & 250.15 & 241.04 \\
\hline & $\mathbf{F e}$ & 8.911 & 9.378 & 3.661 & 4.006 & 5.250 & 5.381 & 41.08 & 42.72 & 40.84 & 39.46 & 255.28 & 246.62 \\
\hline & $\mathbf{Z n + M n}$ & 9.311 & \begin{tabular}{|l|}
9.792 \\
\end{tabular} & 3.930 & 4.306 & 5.381 & 5.486 & 42.21 & 43.97 & 44.41 & 43.26 & 277.59 & 277.36 \\
\hline \multicolumn{2}{|c|}{ L.S.D at $5 \%$} & 2.41 & 2.70 & 1.42 & 1.54 & N.S & N.S & N.S & N.S & 3.03 & 3.52 & 18.73 & 21.31 \\
\hline
\end{tabular}

spray by single $\mathrm{Zn} 0.6 \%$, Mn $0.6 \%$ and $\mathrm{Fe}$ $0.6 \%$ significantly recorded the highest values of maize leaf zinc content, leaf manganese content and leaf iron content, respectively, in the 2016 and 2017 seasons. The increase in chemical properties of leaves and kernels of maize with the application of microelements especially ( $\mathrm{Zn} 0.2 \%+\mathrm{Mn} 0.2 \%$ $+\mathrm{Fe} 0.2 \%$ ) may be due to the synergetic role of microelements in improving directly or indirectly photosynthesis, vital processes in plants such as respiration, protein synthesis , reproduction phase, biochemical and physiological activities. Many investigators reported similar conclusion El-Gharieb et al. (2011) , Sadek and Attia (2011), Shafea and Saffari (2011), Salem and El- Gizawy (2012), Siam et al. (2012) and Balbaa and Awad (2013).

\subsubsection{Interaction effects}

The mean values of zinc, manganese and iron contents of maize leaves were significantly affected by the interaction between nitrogen fertilization and foliar spray of microelements in 2016 and 2017 seasons, as shown in Table (5) . 
Table (5): Effect of nitrogen fertilization rates and foliar microenutrients zinc, manganese and iron and their interaction on leaf and kernel content (ppm) of maize in 2016 and 2017 seasons.

\begin{tabular}{|c|c|c|c|c|c|c|c|c|c|c|c|c|c|c|c|c|c|}
\hline \multirow{3}{*}{ Treatment } & \multirow[t]{3}{*}{$\mid$} & \multicolumn{4}{|c|}{ Nitrogen content \% } & \multicolumn{4}{|c|}{ Zinc content (ppm) } & \multicolumn{4}{|c|}{ Manganese content (ppm) } & \multicolumn{4}{|c|}{ Iron content (ppm) } \\
\hline & & \multicolumn{2}{|c|}{ in leaf } & \multicolumn{2}{|c|}{ in kernel } & \multicolumn{2}{|c|}{ in leaf } & \multicolumn{2}{|c|}{ in kernel } & \multicolumn{2}{|c|}{ in leaf } & \multicolumn{2}{|c|}{ in kernel } & \multicolumn{2}{|c|}{ in leaf } & \multicolumn{2}{|c|}{ in kernel } \\
\hline & & 2016 & 2017 & 2016 & 2017 & 2016 & 2017 & 2016 & 2017 & 2016 & 2017 & 2016 & 2017 & 2016 & 2017 & 2016 & 2017 \\
\hline \multicolumn{18}{|c|}{ Nitrogen fertilization } \\
\hline \multicolumn{2}{|c|}{$75 \mathrm{~kg}$ N/fed } & \begin{tabular}{|l|}
2.32 \\
\end{tabular} & 2.37 & 1.768 & 1.81 & 3.25 & 52.40 & 1.15 & 2.70 & 5.40 & $\mathbf{5 8 . 0 0}$ & 35.20 & 7.35 & 08.95 & 13.05 & 55.80 & $\mathbf{5 8 . 9 0}$ \\
\hline \multicolumn{2}{|c|}{$90 \mathrm{~kg} \mathrm{~N} / \mathrm{fed}$} & 2.53 & 2.57 & 1.927 & 1.96 & 54.10 & 56.85 & 33.20 & 35.25 & 60.40 & 63.55 & 39.10 & 41.90 & 112.80 & 16.85 & 59.85 & 62.40 \\
\hline \multicolumn{2}{|c|}{$105 \mathrm{~kg} \mathrm{~N} / \mathrm{fed}$} & 2.64 & 2.69 & 2.049 & 2.08 & $\mathbf{5 7 . 2 0}$ & $\mathbf{5 9 . 2 5}$ & 35.70 & 37.85 & 63.25 & 65.90 & 43.05 & 45.25 & 115.65 & 19.65 & 63.50 & 65.95 \\
\hline \multicolumn{2}{|c|}{$120 \mathrm{~kg} \mathrm{~N} / \mathrm{fed}$} & 2.74 & 2.79 & 2.125 & 2.16 & $\mathbf{5 8 . 9 0}$ & 60.95 & 37.10 & 39.20 & 66.15 & 69.25 & 45.70 & 48.00 & 119.80 & 23.90 & 65.05 & 68.45 \\
\hline L.S.D at & $5 \%$ & 0.09 & 0.08 & 0.079 & 0.08 & 3.62 & 3.46 & N.S & N.S & 4.63 & 5.12 & N.S & N.S & 5.43 & 4.97 & N.S & N.S \\
\hline \multicolumn{18}{|c|}{ Microelements fertilization } \\
\hline \multicolumn{2}{|c|}{ Zero } & 2.49 & 2.54 & 1.87 & 1.91 & 45.38 & 48.88 & 8.19 & 30.25 & 53.44 & 56.56 & 36.25 & 38.06 & 94.13 & 102.19 & 54.75 & 57.81 \\
\hline Zn & & 2.59 & 2.64 & 2.00 & 2.03 & 62.38 & 64.75 & 8.13 & 39.81 & 60.25 & 62.88 & 40.69 & 43.13 & 111.81 & 115.06 & 1.31 & 63.81 \\
\hline Mn & & 2.53 & 2.58 & 1.969 & 1.99 & 51.06 & $\mathbf{5 3 . 7 5}$ & 31.06 & 33.06 & 69.13 & 71.94 & 43.31 & 45.94 & 108.19 & 111.31 & & 60.81 \\
\hline $\mathbf{F e}$ & & 2.56 & 2.60 & 1.98 & 2.01 & 55.13 & 57.19 & 34.38 & 36.50 & 57.31 & 60.06 & 38.75 & 41.13 & 130.75 & 133.75 & 56 & 67.06 \\
\hline $\mathrm{Zn}+\mathrm{Mr}$ & $+\mathrm{Fe}$ & \begin{tabular}{|l|}
2.61 \\
\end{tabular} & 2.67 & 2.02 & \begin{tabular}{|l|}
2.05 \\
\end{tabular} & \begin{tabular}{|l|}
59.13 \\
\end{tabular} & 62.25 & \begin{tabular}{|c|}
39.69 \\
\end{tabular} & 41.63 & \begin{tabular}{|l|l|}
66.38 \\
\end{tabular} & 69.44 & 44.81 & 47.38 & 126.63 & 129.50 & 38 & 70.13 \\
\hline L.S.D at & $5 \%$ & N.S & N.S & N.S & N.S & 1.21 & 1.32 & 1.23 & 1.27 & 2.10 & 2.35 & 2.13 & 2.00 & 2.24 & 2.85 & & 2.22 \\
\hline & 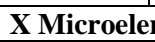 & 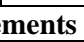 & 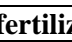 & 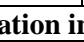 & 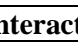 & & & & & & & & & & & & \\
\hline & Zer & 2.23 & 2.30 & 1.62 & 1.66 & 41.75 & 45.00 & 5.25 & 27.00 & 47.25 & 50.25 & \begin{tabular}{|l|}
32.00 \\
\end{tabular} & 34.50 & 0.00 & 7.00 & \begin{tabular}{|l|}
50.50 \\
\end{tabular} & $\mathbf{5 3 . 5 0}$ \\
\hline & $\mathbf{Z}$ & \begin{tabular}{|l|}
2.36 \\
\end{tabular} & 2.42 & 1.82 & 1.85 & 55.25 & 61.00 & 35.00 & 36.25 & $\mathbf{5 5 . 2 5}$ & 56.75 & 34.75 & 36.25 & 106.75 & 50 & 55.75 & 9.00 \\
\hline & Mn & \begin{tabular}{|l|}
2.29 \\
\end{tabular} & 2.33 & 1.77 & 1.82 & 44.50 & 48.00 & 27.25 & 28.50 & \begin{tabular}{|l|}
63.25 \\
\end{tabular} & 66.50 & 37.00 & 39.25 & 103.00 & 106.50 & 50 & 5.50 \\
\hline & $\mathrm{Fe}$ & \begin{tabular}{|l|}
2.32 \\
\end{tabular} & 2.36 & 1.80 & 1.84 & 46.75 & $\mathbf{5 0 . 5 0}$ & $\mathbf{3 1 . 7 5}$ & 33.50 & 51.50 & 54.00 & 33.75 & 35.50 & 124.25 & .50 & & 2.25 \\
\hline & $\mathbf{Z n}+\mathrm{Mn}+\mathrm{Fe}$ & \begin{tabular}{|l|}
2.40 \\
\end{tabular} & 2.46 & 1.8 & 1.87 & \begin{tabular}{|l|}
53.00 \\
\end{tabular} & 57.50 & \begin{tabular}{|l|}
36.50 \\
\end{tabular} & $\mathbf{3 8 . 2 5}$ & \begin{tabular}{|l|}
59.75 \\
\end{tabular} & 62.50 & 38.50 & 41.25 & 120.75 & 75 & 25 & 4.25 \\
\hline & Zero & 2.44 & 2.47 & 1.8 & 1.85 & 45.50 & 49.00 & 27.50 & 29.25 & 53.50 & 56.75 & 34.75 & 36.50 & .75 & 50 & 0 & 6.75 \\
\hline & 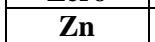 & 2.57 & 2.61 & 1.9 & 1.99 & 63.25 & 65.25 & 37.25 & 38.75 & 59.75 & 62.50 & 39.00 & 42.25 & 00 & & 50 & 1.75 \\
\hline & Mn & \begin{tabular}{|l|}
2.50 \\
\end{tabular} & 2.54 & 1.9 & 1.96 & 49.25 & 51.50 & 29.50 & 32.25 & 66.50 & 70.25 & 41.50 & 45.25 & \begin{tabular}{|l|}
107.00 \\
\end{tabular} & & 0 & 50 \\
\hline & $\mathrm{Fe}$ & 2. & 2.57 & 1.9 & 1.98 & 53.75 & 56 & & & 58.00 & 50 & 25 & 39.75 & 25 & & & 50 \\
\hline & $\mathbf{Z n + M}$ & 2. & 2.65 & 1.9 & 2.01 & \begin{tabular}{|l|}
58.75 \\
\end{tabular} & & & & 5 & 6 & 00 & 45.75 & & & & \\
\hline & & 2. & 2.64 & 1.9 & 2.01 & 0 & & & & & & 75 & 39.25 & 50 & & & 75 \\
\hline & Zn & 2.67 & 2.72 & 2.08 & 2.10 & 65.00 & 66.00 & 39.50 & & 61.50 & 64.50 & 43.00 & 45.75 & 113.00 & & & 6.25 \\
\hline $105 \mathrm{~kg} \mathrm{~N} / \mathrm{fed}$ & Mn & 2.62 & 2.67 & 2.04 & 2.06 & $\mathbf{5 3 . 7 5}$ & 56.00 & 33.00 & 35.00 & 71.00 & 73.00 & 46.00 & 48.00 & 109.50 & 112.50 & 60.50 & 3.75 \\
\hline & $\mathbf{F e}$ & \begin{tabular}{|l|}
2.64 \\
\end{tabular} & 2.69 & 2.07 & 2.09 & 59.00 & 60.25 & 35.75 & 38.00 & $\mathbf{5 8 . 7 5}$ & 61.75 & 40.75 & 43.50 & 131.00 & 133.25 & 67.50 & 69.00 \\
\hline & $\mathrm{Zn}+\mathrm{Mn}+\mathrm{Fe}$ & 2.68 & 2.74 & 2.09 & 2.13 & 61.75 & 63.75 & 41.00 & 43.00 & 69.00 & 71.25 & 47.75 & 49.75 & 128.25 & 130.75 & 69.00 & 72.00 \\
\hline & Zero & 2.69 & 2.74 & 2.08 & 2.12 & 47.75 & 51.25 & 30.75 & 33.00 & 57.00 & 60.25 & 40.50 & 42.00 & 97.25 & 105.50 & 7.75 & 2.25 \\
\hline & $\mathbf{Z n}$ & 2.76 & 2.81 & 2.15 & 2.18 & 66.00 & 66.75 & 40.75 & 42.75 & 64.50 & 67.75 & 46.00 & 48.25 & 117.50 & 120.50 & 65.75 & 8.25 \\
\hline $120 \mathrm{~kg}$ N/fed & Mn & \begin{tabular}{|l|}
2.72 \\
\end{tabular} & 2.78 & 2.11 & 2.14 & 56.75 & 59.50 & 34.50 & 36.50 & 75.75 & 78.00 & 48.75 & 51.25 & 113.25 & 115.75 & 62.00 & 65.50 \\
\hline & $\mathbf{F e}$ & 2.74 & 2.79 & 2.13 & 2.16 & 61.00 & 62.00 & 37.25 & 39.50 & 61.00 & 64.00 & 43.25 & 45.75 & 138.50 & 142.25 & 68.75 & 71.50 \\
\hline & $\mathrm{Zn}+\mathrm{Mn}+\mathrm{Fe}$ & 2.78 & 2.83 & 2.16 & 2.20 & 63.00 & 65.25 & 42.25 & 44.25 & 72.50 & 76.25 & 50.00 & 52.75 & 132.50 & 135.50 & 71.00 & 74.75 \\
\hline L.S.D a & at $5 \%$ & N.S & N.S & N.S & N.S & 2.43 & 2.65 & N.S & N.S & \begin{tabular}{|l|}
4.21 \\
\end{tabular} & 4.70 & N.S & N.S & 4.48 & 5.70 & N.S & N.S \\
\hline
\end{tabular}

It is clear that planting maize under soil fertilized by $120 \mathrm{~kg} \mathrm{~N} /$ fed along with foliar spray by $\mathrm{Zn}, \mathrm{Mn}$ and $\mathrm{Fe}$ significantly gave the maximum values of leaf zinc content, leaf manganese content and leaf iron content, respectively, in the first and second seasons. Similar results were also reported by El-Gharieb et al.(2011), Shafea and Saffari (2011) and Siam et al. (2012).

\section{Conclusion}

From the obtained results of this study, it could be concluded that planting maize (white single cross hybrid Sc 10) under soil fertilized by $120 \mathrm{~kg}$ nitrogen/fed with foliar spray by mixed microelements of ( $\mathrm{Zn} 0.2 \%+\mathrm{Mn} 0.2 \%+$ $\mathrm{Fe} 0.2 \%$ ) maximizes productivity under ELGarbia Governorate, Egypt.

\section{REFERENCES}

Alizadeh O. (2010).Evaluation effect of water stress and nitrogen rates on amount of absorption some macro and microelements in corn plant mycorrhizae and non-mycorrhizae. Adv.Nat. Appl. Sci., 4 (2): 153-158.

Al-Kanh E.R. and Abdullal. A.N. (2008). Effect of inorganic chelated iron fertilizers on growth and yield components of corn (Zea mays, L.). J. Agric. Env. Sci. Alex. Univ., Egypt, 7 (3): 195-204.

A.O.A.C. (1990).Official methods of analysis association of official analysis chemists, $13^{\text {th }}$ Ed., Washington, D.C., USA.

Attia A., Shapiro C., Gomaa M., Aly R. and Omar A. (2011). Response of different corn populations to fertigated nitrogen and certain micronutrients in sandy soil. Agric. Sci., 2: 94-103.

Azeem K.K., Shah S., Ahmad N., Shah S.T., Naz F., Azeem I. and Ilyas M. (2015). Physiological indices, biomass and economic yield of maize influenced by 
humic acid and nitrogen levels. Basic Res. J. Agric. Sci. Rev., 4 (6): 158-163.

Balbaa M.G. and Awad A.M. (2013).Effect of humic acid and micronutrients foliar fertilization on yield, yield components and nutrients uptake of maize in calcareous soils. J. Plant Production, Mansoura Univ., 4 (5): 773 - 785.

Black C.A. (1965). Methods of Soil Analysis. Amer. Soc. of Agron, Inc. Pub., Madison, Wisconsin, USA.

Chapman H.D. and Pratt P.F. (1961).Methods of analysis for soil, plants and waters. Div. Agric. Sci. California Univ., USA .

Egyptian Min. Agric. (2013). Statistic Year Book,

El-Akabawy M.A., Mahdy M.A., Badr M.M.A and Monged N.O. (2001). Effect of biofertilizers and micronutrients on the yield and mineral composition of maize plants at different levels of nitrogen. Egypt. J. Appl. Sci., 16 (8): 332-344.

El-Gedwy M. M. (2007). Maize yield potential as affected by organic and mineral nitrogen, crop residues and tillage. M. Sc. Thesis, Fac. Agric., Moshtohor, Benha Univ., Egypt.

El-Gharieb A. E., El-Hawary M. A., Darwish S. D. and Neowito O.A. R. (2011). Effect of nitrogen source and rate as well as some Microelements treatments on yield and yield components of maize under salt affected soils conditions. J. Plant Product., Mansoura Univ., 2 (3) : 521 - 534.

El-Gizawy N.Kh.B. (2000). Response of maize (Zea mays, L.) to nitrogen and manganese fertilization. Ph.D. Thesis, Fac. Agric. Moshtohor Univ. , Benha Univ., Egypt.

El-Gizawy N.Kh.B. (2005).Effect of irrigation intervals, nitrogen rates and spraying with zinc on yield and agronomic efficiency of nitrogen in maize. Annals of Agric. Sci., Moshtohor, Egypt, 43 (3): 1007-1020.

Gomez K.A. and Gomez A.A. (1984). Statistical procedures for agricultural research. $2^{\text {nd }}$ Ed., John Wiley and Sons, New York U.S.A.

Kanwal S., Rahmatullah A., Ranjha M. and Ahmad R. (2010). Zinc partitioning in maize grain after soil fertilization with zinc sulfate.Int. J.Agric.Biol.,12: 299-302.

Manasek J., Losak T. Prokes K., Hlusek J., Vitezova M., Skarpa P. and Filipcik R. (2013). Effect of nitrogen and potassium fertilization on micronutrient content in grain maize (Zea mays, L.). Acta Univ. Agric., 19 (1): 123-128.

Marschner H. (1995). Mineral Nutrition of Higher Plants. Academic Press Inc. London, UK.

Mehasen S.A.S. and N.A. Saeed (2006). Performance of three maize hybrids under spraying with zink and nitrogen fertilization Agric. Sci., Moshtohor Univ., 44 (3): 887-897.

Michigan State University (1983). MSTAT-C: Micro-computer Statistical Program, Version 2., Michigan State University, East Lansing, Michigan, U.S.A.

Raskar S.S., Sonani V.V. and Patil P.A. (2013).Study of economics of maize as influenced by different levels of nitrogen, phosphorus and zinc. Int 1 . J. Sci. Res. Pub., 3 (10): 1-3.

Rego T.J., Sahrawat K.L., Wani S.P. and Pardhasaradhi G.(2007). Widespread deficiencies of sulfur, boron and zinc in Indian semi-arid tropical soils on-farm crop. J. Plant Nutr., 30: 1569-1583.

Sadek J. G. and Attia M.A. (2011). Phosphours, zinc and manganese fertilization impacts on growth, yield and chemical composition of maize plant (Zea mays, L.). Minufiya J. Agric. Res., 36 (3): 687706.

Salem H. M. and El-Gizawy N.Kh. B. (2012). Importance of micronutrients and its application methods for improving maize (Zea mays, L.) yield grown in clayey soil. Am-Euras. J. Agric. Environ. Sci., 12 (7): 954-959.

Shafea L. and Saffari M. (2011). Effects of zinc $\left(\mathrm{ZnSO}_{4}\right)$ and nitrogen on chemical composition of maize grain. Int ${ }^{`} 1$. J. Agric. Sci., 1 (6): 323-328.

Siam H.S., Abd El-Kader M. G. and Abd ElFattah M.S. (2012). Effect of ammonia gas and some micronutrients on maize plants (Zea mays, L.) I-plant growth and mineral uptake. Aust. J. Basic and Appl. Sci., 6 (3): 462-473.

Stickler F.C. (1964). Row width and plant production studies. $6^{\text {th }}$ Ed., Iowa state Univ., Press, Ames, Iowa, U.S.A.

Verma N.K., Pandey B. K., Singh U. P. and Lodhi M. D. (2012). Effect of sowing dates in relation to integrated nitrogen management on growth, yield and quality of Rabi maize (Zea mays, L.) J. Anim. Plant Sci., 22 (2):324-329. 
إستجابة محصول الذرة الثامية للتسميد النيتروجيني والرش الورقى ببعض العناصر الصغرى

السيد عبد المقصود ابومرزوقة ـ محمد خالد حمدنى

قسم بحوث فسيولوجيا المحاصيل ـ"قسم بحوث التكثيف المحصوليـ معهد بحوث المحاصيل الحقلية

مركز البحوث الزر اعية الجيزة ـ مصر

\begin{abstract}
ملخص

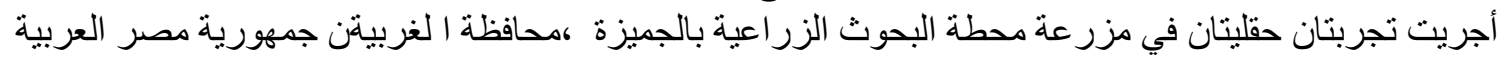

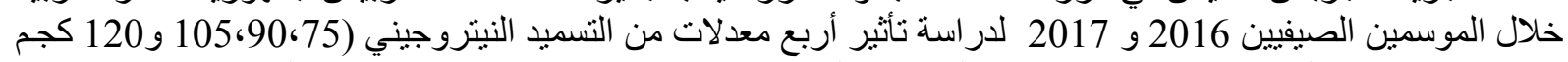

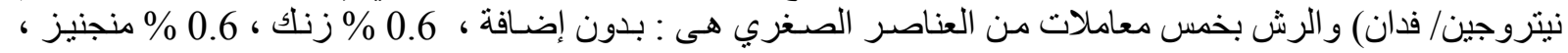

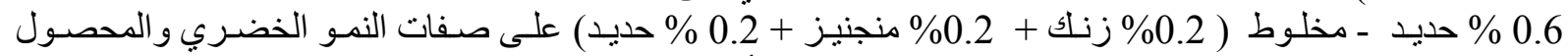

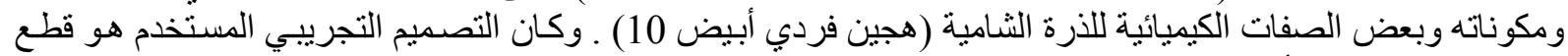

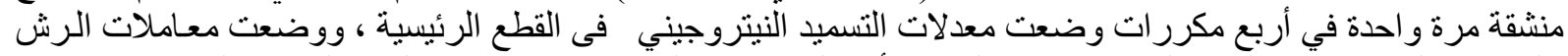

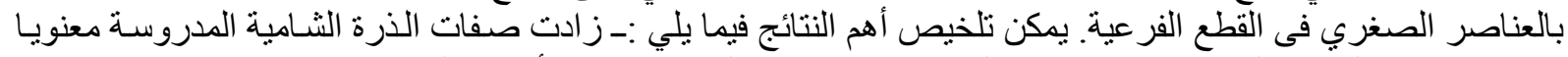

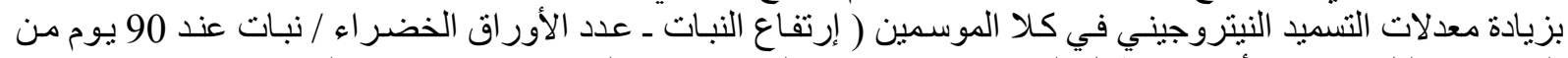

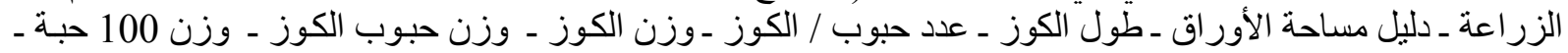

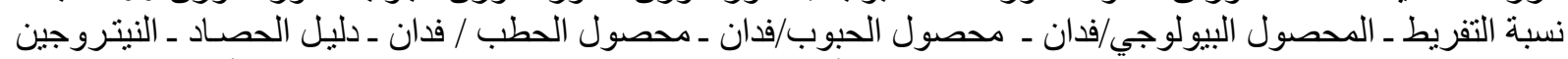

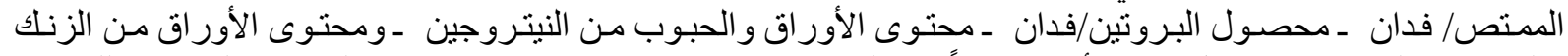

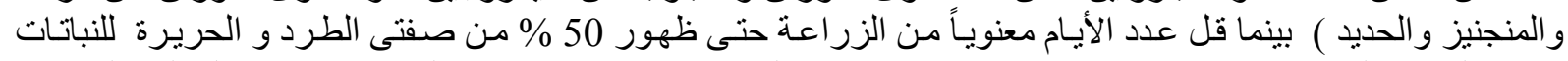

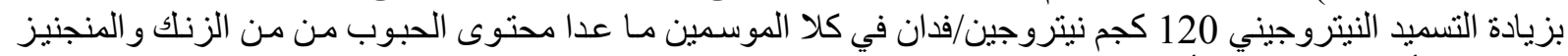

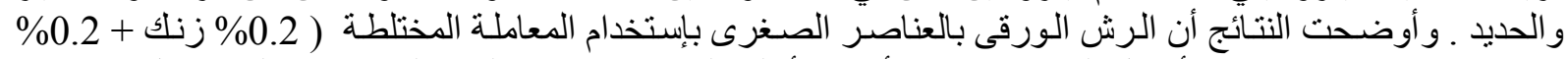

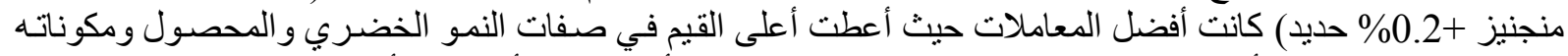

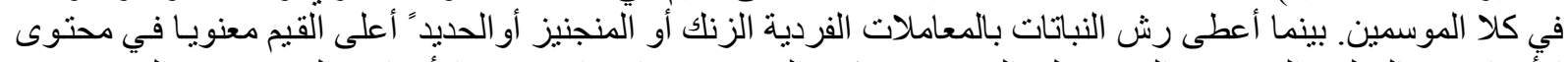

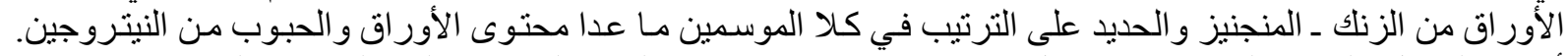

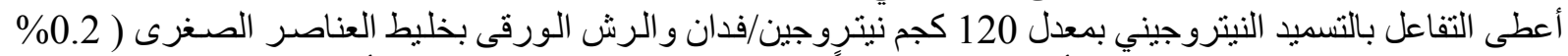

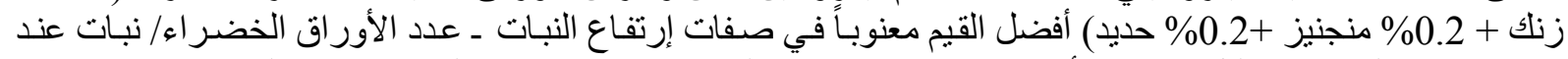

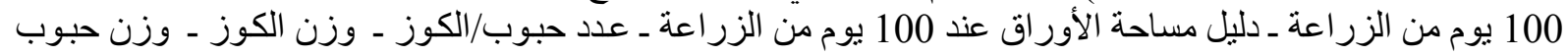

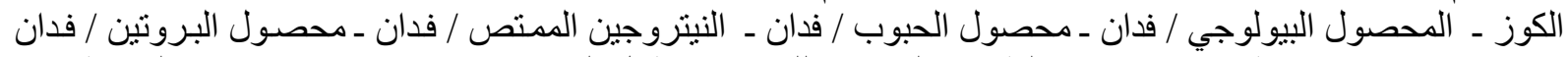

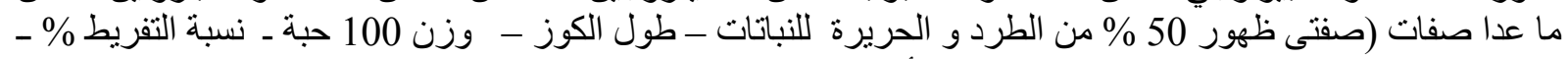

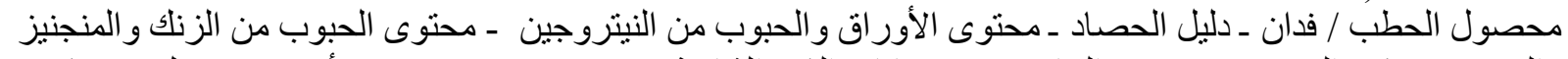

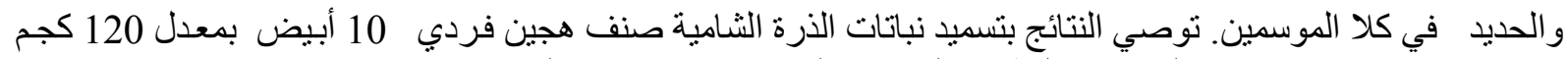

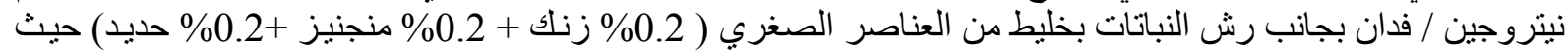

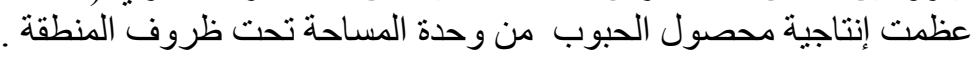

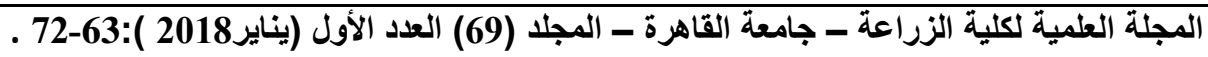

